\title{
Protecting Oak Flat: Narratives of Survivance as Observed Through Digital Activism
}

\author{
Nicholet Deschine Parkhurst \\ Arizona State University \\ Nicholet.Deschine@asu.edu
}

\begin{abstract}
American Indians are increasingly using social media/social network platforms as a tool to influence policy through social change. The activist group Apache Stronghold represents a case of American Indians utilising social media tools to protect Oak Flat and influence federal Indian policy. Oak Flat is sacred Apache land located in Superior, Arizona. United States legislators transferred Oak Flat to the mining company Resolution Copper as part of the omnibus National Defense Authorization Act of 2015. Qualitative analysis of social media content and advocacy tactics - specifically through use of timeline and digital ethnography of Apache Stronghold from 2015-2016 reveal the interrelated nature of on-the-ground efforts, online efforts, solidarity efforts, and legislative support efforts. In sum, these efforts express narratives of survivance, healing, and a future orientation, as a unique dimension of social change.
\end{abstract}

Keywords: American Indian, activism, decolonising methodologies, survivance, social media, Internet studies

\section{Introduction}

Contemporary American Indian activism in the United States has been referred to as a resurgence of the American Indian activism of the mid-20th Century, particularly with regard in the tradition of the American Indian Movement (AIM) and Red Power (Risling Baldy, 2016; Amerman, 2003). But to suggest there is resurgence, or the restart, of activism minimises the efforts of American Indians who continue to engage in present day long-term resistance, and suggests that injustices against American Indians in the United States after the 1970s were non-existent, or were un-fought battles and of no consequence. The framing of contemporary American Indian activist efforts as resurgence is perhaps because of the increased use of visibility via social media, such as Twitter. American Indian activist uses of social media have elevated national and international awareness about the ongoing struggles of injustice in Indian Country related to the protection of sacred sites, homelands, natural resources, and Tribal sovereignty. This study reveals the digital activist efforts of Apache Stronghold to protect sacred land known as Oak Flat. Apache Stronghold is an activist group advocating alongside the San Carlos Apache Tribe, which has been opposed to mining and mineral extraction in Oak Flat for over ten years (Apache Stronghold, 2016). While social media has been discussed in the broader literature as a tool that can be harnessed to raise awareness and bring about social change for oppressed and underrepresented groups of people (Greenleigh, 2013), there is less literature exploring social media activism as an extension of contemporary grassroots activism, and as a narrative of American Indian survivance, described as "an active sense of presence, the continuance of native stories" and the "renunciations of dominance, tragedy, and victimry" (Vizenor, 1999, p.vii).

This less explored area is important to consider especially due to the debates of whether or not social media networks are echo chambers (whether by selective exposure or ideological segregation) of like-minded individuals (Barberá, Jost, Nagler, Tucker, \& Bonneau, 2015) and that cross-ideology exposure especially of political views on Twitter is unlikely (Himelboim, McCreery, \& Smith, 2013). Given the likelihood that social media users, particularly on Twitter, are more likely to be 'Tweeting to the choir', the use of social media by American Indians does more than amplify minority voices, disburse information, and mobilise collective action but also shares the narrative of survivance among those individuals within their networks. 
Survivance is a powerful way to understand that the content of social media posts are very well acts of resistance (Smith, 2012) that celebrate every day stories of American Indian culture, ties to land, and stories of survival.

This research study combines a decolonising and digital methodological approach to a singlecase study investigation of how an American Indian activist group utilises social media and onthe-ground organising to influence social change. The advocacy of Apache Stronghold represents an appropriate case for understanding how activists frame campaigns and mobilise action in spite of the limited opportunities afforded to American Indians and tribes in the United States. Apache Stronghold not only uses social media as a tool to bring about social change but also as a tool to celebrate survival as a form of colonial resistance, and survivance as a means toward encouraging action.

\section{Literature Review}

Writing about American Indian activist uses of social media requires an understanding of the intersection of at least three bodies of literature: activism and social media; decolonising methodologies in social media; and American Indian activism. Read together, these areas of literature show how the amplification of voice that occurs through strategic activist uses of social media relates to the history and commitments of American Indian activism.

\subsection{Activism and Social Media}

\subsubsection{Amplification of Voice}

American Indian Tribes experience a unique situation when it comes to United States federal policy. The federal government in their role as trustee of Indian affairs has a government-togovernment relationship with tribes, and mandates tribes be consulted when federal policies have tribal implications (Richland \& Deer, 2010; Rockwell, 2010; Federal Register, 2000). In the United States, 1.7 percent of the total population, that is 5.2 million people, identify as American Indian or Alaska Native (AI/AN) (U.S. Census Bureau, 2012). As less than two percent of the U.S. population, AI/ANs lack substantive representation in Congress, whether this is few Congressional members being enrolled members of federally recognised tribes or too few Congressional members who have a constituency base of AI/ANs to advocate for (Conner, 2014). In addition, Congressional voting on federal Indian policy is greatly influenced by the presence of a federally recognised American Indian tribe within the district of elected officials (Conner, 2014) versus a district having a substantial number of American Indian constituents (Turner, 2005). The lack of representation in Congress and policy-decision making processes, or too few Congressional members to advocate for AI/ANs, leaves the Native voice out of policy making discussions and ultimately forgotten. Social media has been considered a tool to amplify the voices of oppressed and underrepresented groups of people to raise awareness about issues in the general public and to activate them to take action (Greenleigh, 2013). However, concerns about whether policy decision-makers or mainstream media (Dreher, McCallum, \& Waller, 2016) and even individuals with opposing ideological viewpoints (Himelboim, McCreery, \& Smith, 2013) are listening raise questions about the ability of social media to effectively bring about social change.

While there may be concerns about whether the right political actors are listening, grassroots activist efforts can leverage collective power to bypass media gatekeepers and to amplify issues that may otherwise be forgotten into the public conscious. For example, the Trayvon Martin murder case-in which a young Black teenager was killed by police - highlighted one major aspect about the power of social media. Initially, national mainstream media mostly ignored the case but after weeks of increasing social media attention the national media picked up the story (Graeff, Stempeck, \& Zuckerman, 2014). The public voiced the issue as a top-tier story requiring 24-hour coverage. The magnitude of people's interest in the case and eventual national news coverage demonstrated the power that social media can have in influencing traditional media gatekeepers (Greenleigh, 2013). While traditional media may help to legitimise social media movements, as was the case for \#IdleNoMore in its first six weeks, the 
media's framing of a movement may decenter Indigenous peoples preference on how their issues are discussed (Moscato, 2016). Idle No More is a grassroots Indigenous movement in Canada that drew attention to the importance of Indigenous sovereignty and the protection of treaty rights (John, 2015).

\subsubsection{Collective Action}

Social media is also a tool to mobilise collective action to bring about social change. The Arab Spring, the Occupy Wall Street movement, and Spain's los indignados are examples of the organisation of collective action for mass political influence through social media. Social media can mobilise collective action more quickly than through traditional methods (Valenzuela, 2013) as well as mobilise collective actions across geographic areas that may have previously been a barrier for grassroots activist organising. The mobilisation of collective actions manifest in various forms, including wide-spread demonstrations and protests across multiple locales, the convergence of people in one location, and even the collective act of thousands of people each engaging in individual tasks. For example, the \#StandwithStandingRock and \#NoDAPL activist movement highlights the manifestation of collective actions in various forms from solidarity demonstrations in cities across the United States and worldwide (Democracy Now!, 2016), the exponential growth of up to 10 thousand 'water protectors' camping near the pipeline's crossing of the Missouri River (Medina \& Davis 2016; Loeffelholz Dunn, 2016), and individuals, tribes, and cities divesting from banks funding the Dakota Access Pipeline (Chappell, 2017; Brainerd Dispatch, 2017; Grinberg, 2016).

Digital activism has been considered an important component to effective contemporary activism. On-the-ground activist efforts and digital activist efforts can both contribute to the end goal of raising awareness to a larger audience on a particular issue, and mobilising individuals on the other side of a screen. Maile, Executive Director and Founder of English at Work, states that you need the people who chain themselves to the tree, the people who work 30 years to save the tree, and you need the people that use social media as a part of the overall awareness strategy; but you need all the elements together to be most effective (Harlow \& Guo, 2014). This being the case, digital activist efforts in Indian Country benefit from the foundation of on-the-ground activist networks (e.g. American Indian Movement, Indigenous Environmental Network) and the proliferation of Indian Country issues being raised online, which presses the demand for media coverage.

\subsection{Decolonising Methodologies}

\subsubsection{Decolonising Social Media Studies by Celebrating Survival}

Social media studies often utilise methods that quantify aspects of the social media experience by collecting data characteristics such as the exposure of social media posts, the sharing and diffusion of information, number of times specific hashtags are used, or the magnitude and analysis of social networks. These types of data analytics can be beneficial for understanding and potentially predicting social phenomena especially in situations of policy decisions or in the case of activism to further understand the influence and impact of social media activism. For example, researchers (Vigil-Hayes, Duarte, Deschine Parkhurst, \& Belding, 2017) tracked the connective actions of Native American advocates on Twitter to gain an in-depth understanding of the ubiquitous and pressing political issues that can and should be addressed by political actors. Consequently, the quantification of data naturally leads to measuring impact, influence, or importance, which, in the case of studying digital activism, draws challenges since events, news, and trends can shift quickly.

Social media studies in a way are about how the collection, measurement, and interpretation of data can be used to influence outsiders who then can make decisions about an issue or community. Since decolonising methodologies aim to empower Indigenous communities (Smith, 2012; Jacob, 2013) the decolonisation of social media studies should center Indigenous perspectives and their experiences with social media, and, much like mass media, provide a counter perspective to colonial discourses (Knopf, 2010, Smith, 2012). For example, Knopf (2010), in a study about decolonising media in Canada, states that Aboriginal peoples by 
controlling and creating their own media are focusing on the needs and priorities of their own people as well as offering opposing perspectives on current issues. Furthermore, the decolonising methodology 'celebrating survival,' which focuses on how Indigenous peoples celebrate "a sense of life, and diversity, and connectedness" (Smith, 2012, p. 146), can empower individuals and communities who, in the case of Indigenous struggle, express narratives of survival (or survivance) via social media.

\subsection{American Indian Activism}

Research on American Indian activism in the United States has focused on American Indian civil rights activists and ethnic pride particularly of the 1960s and 1970s through the efforts of American Indians who occupied Alcatraz Island, the American Indian Movement (AIM) and Red Power. Yet, activism and advocacy in Indian Country has persisted. Long-term resistance efforts include the Navajo matriarchs at Black Mesa on the Navajo Nation who have resisted relocation for 30-years; the strong tribal and American Indian opposition to the expansion and development of a ski resort on the San Francisco Peaks since 1969 and the resort's use of reclaimed waster water and production of man-made snow; the $45+$ year efforts to eliminate stereotypical Native American images and team names in media, including the Washington NFL team's name the Redskins; and the focus of this study, the 10+ year long-term efforts of the San Carlos Apache Tribe to protect sacred land known as Oak Flat located in Arizona from mineral extraction.

Further, in recent years there has been an increase in the use of social media platforms and digital tactics to raise awareness about a multitude of injustices American Indians face such as the protection of sacred sites and the environment against mining or commercial development (e.g. Keystone Pipeline, San Francisco Peaks), violence against Native women, the representation of Natives in sports and media, the cultural appropriation and theft of cultural property and practices, and civil rights. In the United States, social media has been used to circulate Internet memes related to the Free Leonard Peltier movement (Lenhardt, 2016); to express solidarity with Idle No More and First Nations people's defense of Indigenous sovereignty and treaty rights; to draw attention to Missing and Murdered Indigenous Women through the use of the hashtag \#IdleNoMore and subsequent round dance flash mobs in malls and parks (John, 2015; Walker, 2014); and to disseminate information and organise collective action through Facebook and Twitter account pages setup for specific causes and their applicable hashtags.

Hashtag use in American Indian political discourse on Twitter have been categorised in one study as representing topics of identity, civil rights, current events, and environmental issues (Vigil-Hayes, Duarte, Deschine Parkhurst, \& Belding, 2017). The use of hashtags in American Indian activist efforts not only can draw attention to specific causes but also can be used to support a greater movement of similar injustices across tribal groups, or even to connect to the global Indigenous community. For example, \#SavethePeaks refers directly to the efforts to protect the San Francisco peaks where as \#ProtectSacredSites refers to a conglomerate of sacred sites protection efforts, which may include the San Francisco Peaks, Standing Rock, and Oak Flat. The hashtag \#Indigenous has been discussed as an overarching all encompassing label in which everything "relevant to Indigenous, Aboriginal, or Native American peoples" may be attached (Vigil-Hayes, Duarte, Deschine Parkhurst, \& Belding, 2017). Furthermore, hashtags can also be Indigenised to not only present alternative discourses but also to "support efforts for self-determination in a very modern and public context" (Risling Baldy, 2016, p.94). For example, the hashtag \#NotYourTonto was generated to protest and counter the film The Lone Ranger's portrayal of American Indian peoples in stereotypical characters and Hollywood's failure to promote the representation of American Indian people in media (Risling Baldy, 2016).

\section{Methodology}

The proliferation of digital activist efforts related to American Indian issues leads to the overarching question and focus of this study: "How does an American Indian activist group 
utilise social media and on-the-ground organising to influence social change?” Specifically, by studying the efforts of Apache Stronghold, this study reveals interrelated digital and on-theground aspects of Oak Flat activism, as well as the narratives of survivance portrayed by the activist group Apache Stronghold through social media.

There were two steps to this qualitative single-case study. In the first step, a timeline of Oak Flat activist 'critical events' was developed based on online data sources such as websites, social network sites, and local and national news sources. 'Critical events' refers to junctures in which the actors in the movement recognise they cannot go back to their sense of what happened before, that history is irrevocably changed due to changes in the social world around them (Sewell, Jr., 2005). This study is comprised of the critical events surrounding Oak Flat activism, which took place between December 2, 2014, the date the Southeast Arizona Land Exchange and Conservation Act of 2013 was introduced in the U.S. House of Representatives, through December 31, 2015.

The timeline was integral to the second step, which consisted of qualitative analysis of social media content associated with critical events. This qualitative analysis was conducted with a goal of centering the narratives, experiences, goals and social contexts of the American Indian activists, in short, de-centering the white or non-Native gaze by foregrounding the American Indian activists' goals.

\subsection{Method: Data Gathering, Sampling, and Analysis}

Gathering and analysing data was a detailed and simultaneous process, which I describe in two steps. I first compiled a timeline of critical events relating to Oak Flat between December 2014 and December 2015 that included a variety of San Carlos Apache Tribe efforts, legislative efforts, efforts of the activist group Apache Stronghold, and ally efforts. These events were compiled from online public data sources such as websites, Facebook, Twitter, Instagram, local and national news sources, and civic engagement platforms. Examples of critical events include the creation of a petition on President Barack Obama's online civic engagement platform, 'We The People', Apache Stronghold's creation of a Tumblr account on March 1, 2015, Congressional legislation introduced in the Senate and House, statements made by the U.S. Department of the Interior Secretary (Jewell, 2014), the White House response to the 'We The People' online petition (Gillette, 2015), the start of Oak Flat occupation, Apache Stronghold's calls for action, spiritual runs and ceremonies, protests and demonstrations, and the uploading of unique digital content.

Simultaneously, as I was compiling the timeline I read social media statuses, articles, and websites; watched videos and listened to audio; reviewed photos; and clicked attached URL links located within the digital content of identified critical events. The goal of this digital ethnographic process was to obtain a diversity of media content and emerging patterns and themes. During this process I reviewed, documented, wrote descriptions, and took notes as to the nature and themes of content, from a wide range of media, till I reached saturation of data or in other words when I started to identify repeated content; for example, a popular picture of Apache Stronghold activist Naelyn Pike is standing in Times Square holding a bow and arrow (see Figure 1). I also reviewed all of Apache Stronghold's social media accounts (e.g. Facebook, Tumblr, Twitter, and Instagram) specifically looking at the content and types of social media they shared. 


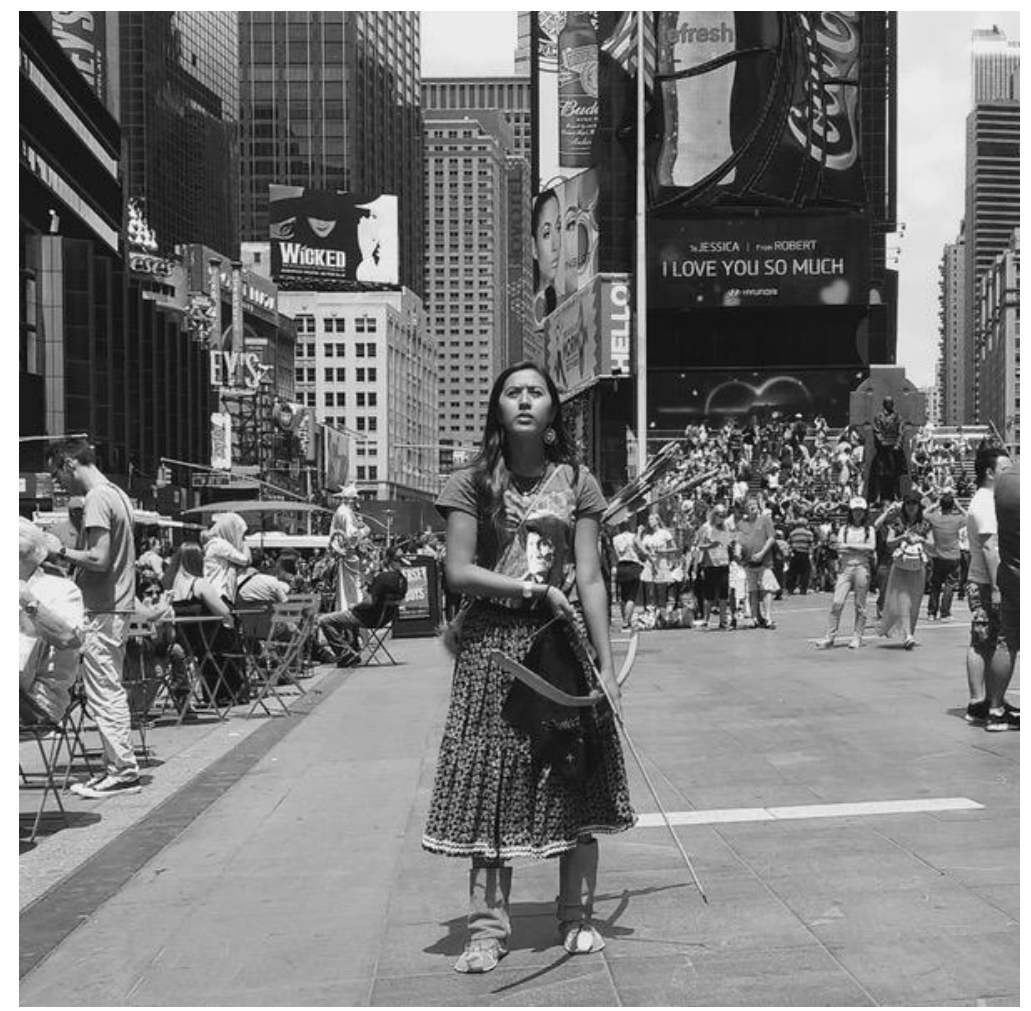

Figure 1. Naelyn Pike holding a bow and arrow in New York Times Square, Photo by Standing Fox (Revkin, 2015)

Initially, my notes did not code the content based on a priori categories (Corbin \& Strauss, 2015). As I reviewed each new piece of data I noticed patterns and themes appearing such as the inclusion of specific hashtags, memes, art, and the nature of text. I then back coded the content and future content based on those observed patterns. If a new pattern was observed that had not been previously seen and didn't fit with an already existing code, a new code was created; I did not, however, go back and recode the previous data, as I chose to preserve the insights gathered through my ethnographic process. In this way, I began to observe the threads of narratives of survivance emerging. Throughout these dual processes, I digitally archived data through screenshots; saving websites and news articles as PDFs; saving website and video URLS, Tweets, Facebook statuses, and news articles.

\section{Results}

The results of this digital single-case study indicate aspects of social media content, such as the structure of Tweets and Facebook status, emergent themes of content, relevant hashtags, and the categorisation of activists' efforts: on-the-ground, online, solidarity, and legislative efforts.

\subsection{Case Background: Apache Stronghold}

Since 2005, the San Carlos Apache Tribe has stopped 13 Congressional attempts to transfer sacred land known as Oak Flat, located near Superior Arizona, to the mining company Resolution Copper. However, on December 4, 2014 Congressional action bypassed federaltribal government-to-government consultation policy and passed the Southeast Arizona Land Exchange and Conservation Act of 2013 (H.R. 687) as an amendment (i.e. additional provision) to the National Defense Authorization Act for Fiscal Year 2015 (NDAA). The provision was made publicly known at 11:00PM on December 2, 2014, the night before the House of Representatives vote. San Carlos Apache Chairman Terry Rambler immediately criticized the last-minute provision (Toensing, 2014), a White House petition on 'We The People' was created on December 4th, and the hashtag \#apachelandgrab was first Tweeted on December 
5th with a call to action and a URL link to the White House petition. On December 19th, the NDAA was signed into law.

In January 2015, the San Carlos Apache Tribe announced a four-pronged approach to save Oak Flat that includes grassroots efforts, legislative actions, legal actions, and educational outreach campaigns (Toensing, 2015; Rambler, 2015). Physical occupation of Oak Flat by grassroots activists started February 9th and by March these activists became known as the Apache Stronghold per the creation of a Tumblr microblog and creation of accounts on other social network platforms. Apache Stronghold continues to pursue on the ground activist efforts coupled with digital activism to raise awareness about efforts to protect Oak Flat. Although Apache Stronghold officially formed in 2015 on social network platforms, others primarily used Twitter as early as 2011 to bring attention to the Congressional activity about Oak Flat.

\subsection{Structure of Apache Stronghold Social Media Posts}

The structure of Apache Stronghold's social media posts such as Facebook statuses and Tweets could be generally described as having the following attributes: hashtags, URL links, embedded visual/audio attachments, and text and symbols. Social media posts at times included cross-platform URL links to share content to and from multiple social network sites such as YouTube, Vimeo, Instagram, Facebook, Twitter, and Tumblr. The structure of social media content helps to understand how activists utilise a combination of social media tools to disseminate information, engage viewers in content, and to document on-the-ground activist efforts. Reviewing the attributes of social media posts further gives insight into the interplay between activist efforts online, across social media platforms, and on the ground. Figure 2 is an example of an Apache Stronghold Twitter post, which includes both hashtags and a visual attachment.

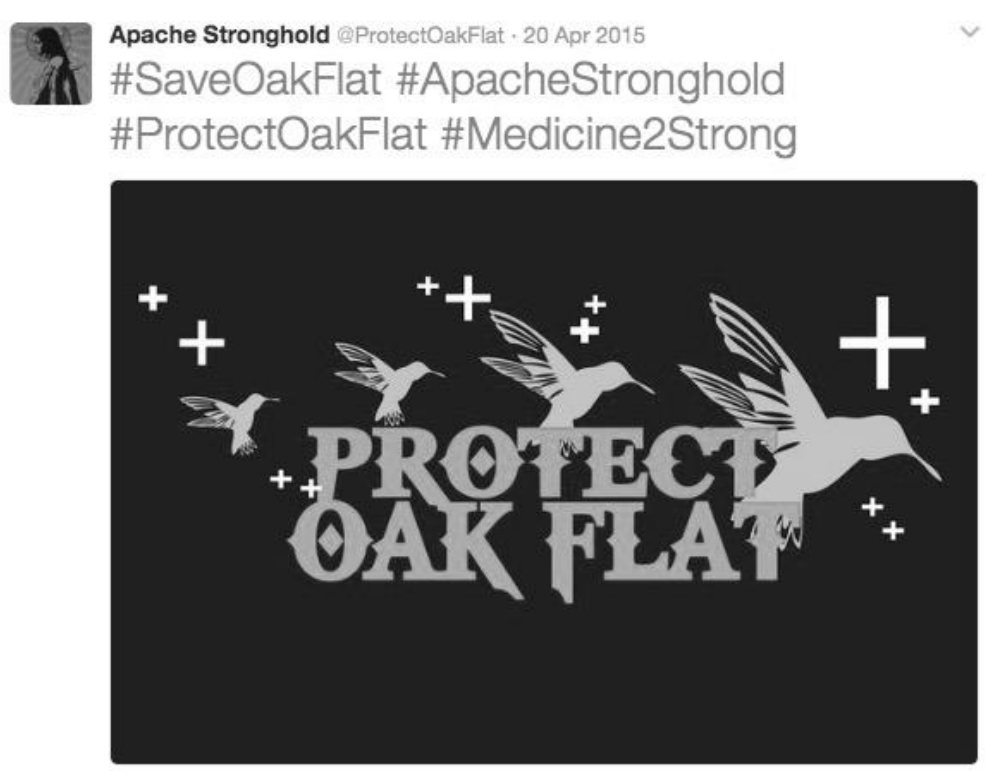

Figure 2. Screenshot of Apache Stronghold's first Twitter post from April 20, 2015. The post is a combination of four hashtags and an image macro (i.e. meme). The image macro depicts four hummingbirds, cross symbols, and the text "PROTECT OAK FLAT".

Text posts are generally more informative in nature to disseminate statements, press releases, information about Congressional efforts, challenging claims that minimise the importance of an issue, and may include calls to action. Calls to action could be categorised into the following calls: supporting petitions, calling congressional leaders or local organisations, sharing of posts, fundraising requests, and shows of solidarity. Table 1 lists four examples of Apache Stronghold's social media text-only posts on Facebook and Twitter. 
@ProtectOakFlat "The rain and thunder came after a weekend of singing! We are also joined by Nihi gaal bee iina Diné walkers \#Blessings \#protectoakflat" (Twitter, May 4, 2015).

$@$ ProtectOakFlat: "Thank you for sharing, the youth are a big reason of why we need to fight for the sacred land. \#SaveOakFlat" (Twitter, June 24, 2015).

@ProtectOakFlat: “\#SaveOakFlat as \#holyplace for \#Apache // sign \#Petition to make it a National Monument. http://wh.gov/iIcKO \#ProtectOakFlat” (Twitter, August 5, 2015).

@Apache-Stronghold-802193869856079/

“++++URGENT CALL TO ACTION++++

As we prepare to enter DC tonight. We got word from Washington that we NEED YOU to call Sen. Heinrich from New Mexico, Sen. Franken from Minnesota, Senator Testor from Montana. WE NEED YOU TO CALL THEM if they represent you! WE NEED them to COSPONSOR the Save Oak Flat Act in the Senate!!

if so the repeal could be introduced by Thursday!!

$++++$

thank you for your support!" (Facebook, November 3, 2015)

Table 1: Examples of Apache Stronghold's Social Media Text Posts on Facebook and Twitter

Visuals such as photographs or videos are also included in Apache Stronghold's social media posts, which engage and speak to viewers on a different level than text-only posts. Videos may convey individual testaments of the cultural significance of land, connection to land, and spirituality, the landscape of Oak Flat, or document on-the-ground activist efforts.

Photographs may include moments of movement such as individuals on a walk, or drumming and singing, individual or group pictures, and pictures of Oak Flat landscape. Figure 3 is an example that depicts the structure of an Apache Stronghold Facebook post that includes text and a video attachment. 
It's amazing how Leaders fail in their knowledge of the most precious gift to life. We, the People must stand in Unity to protect all our children and those yet to be born to have a chance to live, so Repeal the Land Exchange.

Support the Save Oak Flat Act!!!

Sign the petition.. Write your congressional representatives and senators.

Get the word out. Share.

Knowledge of Arizona's actions against their own constituents is an issue. All

of Arizona still does not know what is going on or choose to ignore it.

Wendsler Nosie Sr., former Democratic Electoral College and

District 1 Executive committee member, Democratic Party

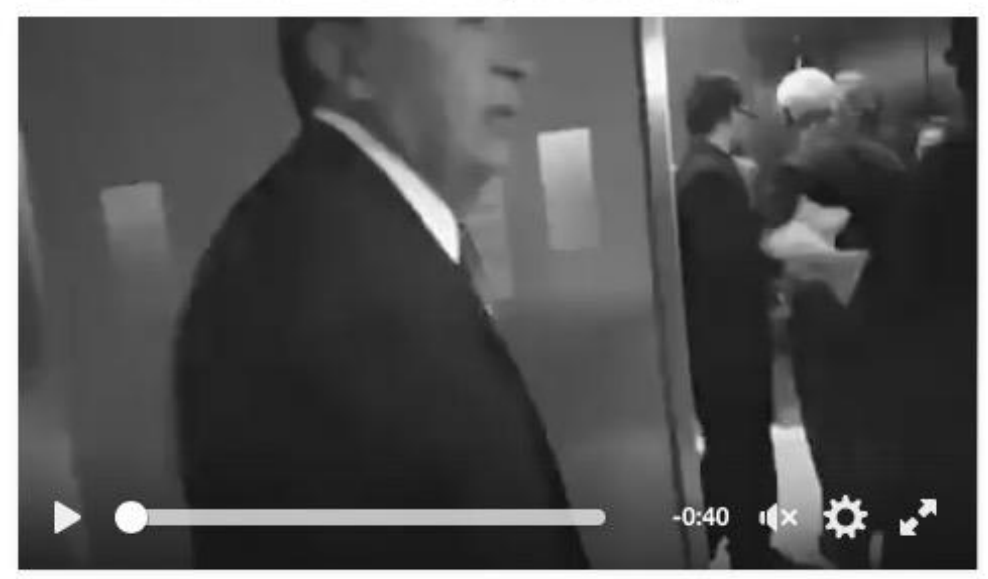

Figure 3. Screenshot of Apache Stronghold's Facebook post from October 31, 2015. This is an example of a post with text and a video attachment. The video depicts on-the-ground activist efforts of the person filming and following another person into an elevator and asking the people in the elevator a question. The text depicts a call to action for people to sign a petition and to contact congressional leaders.

Memes are a variation on photo posts, which include text right on the image, which are also very effective at communicating a specific message. Popularly known as memes, in the scholarly literature, memes are more accurately known as image macros. An example of a popular stylised image macro includes an image of an Apache female youth in traditional regalia often worn in the Apache Sunrise Dance, a coming-of-age ceremony, with the text "PROTECT Sacred Oak Flat" (see Figure 4). Lastly, there appears to be an increase in the inclusion of Apache youth activist Naelyn Pike in photo posts. Naelyn has appeared in almost all of the video attachments I sampled. 


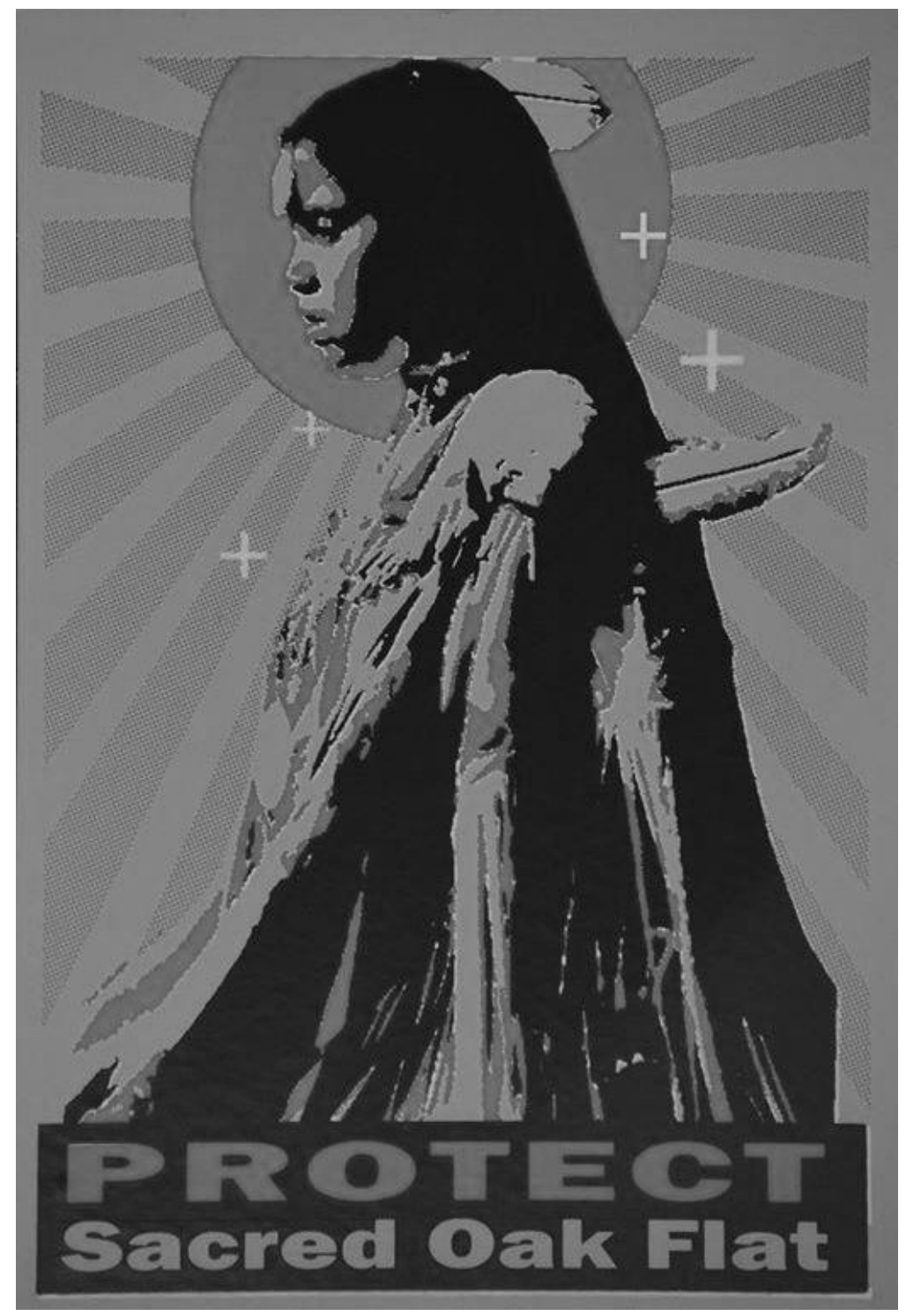

Figure 4. Image macro from Apache Stronghold's Facebook post on March 15, 2015. The image macro depicts an Apache female youth in traditional regalia often worn in the Apache Sunrise Dance and is accompanied with the text "PROTECT Sacred Oak Flat".

\subsection{Emerging Themes.}

Some of the emerging themes from social media content surrounding Oak Flat activism include the dissemination of information (e.g. negative consequences to the land, challenges to economic claims, history of legislative efforts to exchange the land), showcasing culture and spirituality (e.g. spiritual run, traditional practices), spiritual significance of the land, importance of youth, as well as contemporary acts of resistance (e.g. occupation of Oak Flat, Navajo Nation sit-in). Emergent themes in the content of Apache Stronghold's social media point to the overarching presence of culture and spirituality across themes. For example, the emerging theme 'showcasing culture and spirituality' came about because of social media content that depicted or discussed the active expression of cultural heritage or spirituality, such as photos of people holding items of cultural significance.

However, the presence of culturally significant items did not exclude social media content from contributing to other emerging themes. For example, Figure 1 of Naelyn Pike holding a bow and arrow in the New York Times Square was an example of the emerging theme 'acts of resistance' (see Table 2). This photo depicts Naelyn wearing moccasins and a camp skirt standing in what appears to be an archery stance with her hands gripping a bow and holding 
the arrow on the bowstring (the arrow points downward). The symbolism and active presence of Naelyn standing in this manner with items of cultural significance and the skyscrapers in the background portrays Naelyn as a protector ready for what comes her way. Table 2 lists examples of emerging themes observed through the digital ethnographic process.

\begin{tabular}{|c|c|c|c|}
\hline $\begin{array}{l}\text { Dissemination of } \\
\text { Information }\end{array}$ & $\begin{array}{l}\text { Showcasing } \\
\text { Culture and } \\
\text { Spirituality } \\
\end{array}$ & $\begin{array}{c}\text { Spiritual } \\
\begin{array}{c}\text { Significance of } \\
\text { Land }\end{array} \\
\end{array}$ & Acts of Resistance \\
\hline $\begin{array}{l}\text { Sharing the link to the } \\
\text { "We The People" } \\
\text { petition titled "Stop } \\
\text { Apache Land Grab" }\end{array}$ & $\begin{array}{l}\text { Spiritual runs, } \\
\text { ceremonies, and } \\
\text { blessings }\end{array}$ & $\begin{array}{l}\text { Image macro of } \\
\text { hummingbirds and } \\
\text { symbols of stars with } \\
\text { the text "PROTECT } \\
\text { OAK FLAT" }\end{array}$ & $\begin{array}{l}\text { Occupation of Oak } \\
\text { Flat and living off the } \\
\text { land }\end{array}$ \\
\hline $\begin{array}{l}\text { YouTube video } \\
\text { describing the specific } \\
\text { type of mining to be } \\
\text { conducted and the } \\
\text { impact to the land }\end{array}$ & $\begin{array}{l}\text { Image macro of an } \\
\text { Apache female youth } \\
\text { in traditional regalia } \\
\text { often worn in the } \\
\text { Apache Sunrise Dance, } \\
\text { a coming-of-age } \\
\text { ceremony }\end{array}$ & $\begin{array}{l}\text { Descriptions about } \\
\text { Oak Flat's purpose in } \\
\text { Apache Sunrise Dance, } \\
\text { a coming-of-age } \\
\text { ceremony }\end{array}$ & $\begin{array}{l}\text { Apache Stronghold } \\
\text { activist Naelyn Pike } \\
\text { standing in Times } \\
\text { Square holding a bow } \\
\text { and arrow }\end{array}$ \\
\hline $\begin{array}{l}\text { Apache Stronghold } \\
\text { website documenting } \\
\text { the history of the San } \\
\text { Carlos Apache Tribe's } \\
\text { efforts to Save Oak Flat }\end{array}$ & $\begin{array}{l}\text { Virtual calling out (i.e. } \\
\text { shaming) as a cultural } \\
\text { practice of social } \\
\text { control and } \\
\text { accountability }\end{array}$ & $\begin{array}{l}\text { Photos and videos of } \\
\text { prayers, dancing, } \\
\text { singing, and } \\
\text { gatherings while in } \\
\text { Oak Flat }\end{array}$ & $\begin{array}{l}\text { Women and youth } \\
\text { prominently placed in } \\
\text { the front row of } \\
\text { marches and photo } \\
\text { opportunities }\end{array}$ \\
\hline $\begin{array}{l}\text { Sharing event } \\
\text { information and where } \\
\text { Apache Stronghold or } \\
\text { San Carlos Apache } \\
\text { Leaders will be } \\
\text { speaking }\end{array}$ & $\begin{array}{l}\text { Pictures of people with } \\
\text { items of cultural } \\
\text { significance }\end{array}$ & $\begin{array}{l}\text { Stories about the San } \\
\text { Carlos Apache people's } \\
\text { ties to the land }\end{array}$ & $\begin{array}{l}\text { Connecting with and } \\
\text { supporting other } \\
\text { American Indian } \\
\text { activist groups }\end{array}$ \\
\hline
\end{tabular}

Table 2: Examples of Emerging Themes from Social Media Content Related to Oak Flat Activism

\subsection{Hashtags}

Hashtags are keywords or a phrase preceded with the hash symbol (\#) that people use in their social media posts either to connect the post to similar posts (Small, 2011), or to express identification or membership in a group (Cunha, Magno, Goncalves, Cambraia, \& Almeida, 2014). The widespread use of hashtags originated on Twitter but has extended to other social media platforms such as Facebook, Tumblr, and Instagram. Social media pertaining to Oak Flat activism were generally accompanied by hashtags.

I identified four primary hashtags and four supplemental hashtags that were associated with Oak Flat activism (see Table 3). According to a search on TOPSY.com, a social media analytics search engine, the first Tweet using the movement's common hashtag \#SaveOakFlat was created in 2011 by Earthworks, a nonprofit organisation dedicated to protecting the environment from mineral and energy development. The tweet included information about a Congressional Hearing taking place on the Southeast Arizona Land Exchange and Conservation Act. Identifying the first use of the hashtag, \#SaveOakFlat, further highlights that the issues surrounding the Oak Flat area were being raised on social media since 2011. Other uses of the movement's common Twitter hashtags share information about critical events related to Oak Flat and to call on the audience to take action. The hashtag \#ApacheLandGrab was first Tweeted on December 5, 2014 with a call to action and a link to the 'We The People' petition. The hashtag \#ProtectOakFlat was first used on February 9, 2015 in conjunction with 
three other hashtag variants (\#occupyoakflat, \#saveoakflat, \#oakflat), with no other text and a photo attached. The photo depicted land, trees, and a campsite assumed to be located within Oak Flat. Posts may also be accompanied by the supplemental hashtags, which connect activism on Oak Flat to a larger phenomenon of Native American digital activism, connecting this specific cause to other local, national, and international issues on the exploitation of land, desecration of other Indigenous sacred sites, and a larger movement of solidarity in Indigenous issues. Table 3 lists examples of primary and supplemental hashtags observed through the digital ethnographic process.

\begin{tabular}{|l|l|}
\hline \multicolumn{1}{|c|}{ Primary Hashtags } & \multicolumn{1}{c|}{ Supplemental Hashtags } \\
\hline \#apachelandgrab & \#nativepride \\
\#occupyoakflat & \#honorthetreaties \\
\#saveoakflat & \#protectsacredland \\
\#protectoakflat & \#RespectExistenceorExpectResistance \\
\hline
\end{tabular}

Table 3: Examples of Hashtags Associated with Oak Flat Activism

\subsection{Types of Activist Efforts}

Critical events surrounding Oak Flat activism could be categorised into the following types of activist efforts: on-the-ground activism, online efforts, solidarity efforts, and legislative support (see Table 4 for examples). While I categorise certain critical events as a specific type of effort, critical events may be characteristic of more than one type of effort. For example, I categorised the Navajo Nation sit-in, where Oak Flat activists joined Navajo activists to protest Arizona Senator John McCain, as a solidarity effort because the action took place on the Navajo Nation in coordination with Navajo activists. This critical event could also be categorised as on-the-ground activism because of the in-person interaction of activists with each other, with the community, and with Senator McCain. Table 4 lists examples of activist efforts by category as observed through the digital ethnographic process.

\begin{tabular}{|c|c|c|c|}
\hline $\begin{array}{c}\text { On-the-Ground } \\
\text { Activism }\end{array}$ & Online Efforts & Solidarity Efforts & Legislative Support \\
\hline $\begin{array}{l}\text { Physical occupation of } \\
\text { Oak Flat }\end{array}$ & $\begin{array}{l}\text { Creation of We The } \\
\text { People petition titled } \\
\text { "Stop Apache Land } \\
\text { Grab" on the White } \\
\text { House civic } \\
\text { engagement platform }\end{array}$ & $\begin{array}{l}\text { Walk to Save Oak Flat } \\
\text { - Mother and } \\
\text { daughter team who } \\
\text { walked from Oregon } \\
\text { to Oak Flat in a stand } \\
\text { of solidarity }\end{array}$ & $\begin{array}{l}\text { H.R.2811, Save Oak } \\
\text { Flat Act - Call of action } \\
\text { to support the } \\
\text { legislation, and } \\
\text { activists meeting with } \\
\text { the sponsoring Arizona } \\
\text { Congressman Raúl } \\
\text { Grijalva }\end{array}$ \\
\hline $\begin{array}{l}\text { Awareness event with } \\
\text { activist speakers, art, } \\
\text { music }\end{array}$ & $\begin{array}{l}\text { Video titled "Protect } \\
\text { Oak Flat: Saving } \\
\text { Apache Sacred } \\
\text { Grounds" uploaded to } \\
\text { Vimeo }\end{array}$ & $\begin{array}{l}\text { Navajo Nation sit-in - } \\
\text { Oak Flat activists } \\
\text { joined Navajo activists } \\
\text { to protest Arizona } \\
\text { Senator John McCain }\end{array}$ & $\begin{array}{l}\text { S.2242, Save Oak Flat } \\
\text { Act - Call to action to } \\
\text { support the legislation, } \\
\text { and activists meeting } \\
\text { with the sponsoring } \\
\text { Vermont Senator } \\
\text { Bernie Sanders }\end{array}$ \\
\hline $\begin{array}{l}\text { Spiritual run and } \\
\text { ceremony in front of } \\
\text { the U.S. Capital in } \\
\text { Washington DC (this } \\
\text { is one type of event on } \\
\text { Apache Stronghold's } \\
\text { journey to Washington } \\
\text { DC }\end{array}$ & $\begin{array}{l}\text { Virtual calling out (i.e. } \\
\text { shaming) of an } \\
\text { Arizona local Native } \\
\text { American non-profit } \\
\text { organisation for } \\
\text { accepting funding } \\
\text { from Resolution } \\
\text { Copper }\end{array}$ & $\begin{array}{l}\text { 18-day fast by allies in } \\
\text { solidarity with the San } \\
\text { Carlos Apache Tribe } \\
\text { and Apache } \\
\text { Stronghold }\end{array}$ & $\begin{array}{l}\text { Naelyn Pike testifying } \\
\text { in a House of } \\
\text { Representatives } \\
\text { Executive Session } \\
\text { Forum on Protecting } \\
\text { Native American } \\
\text { Sacred Sites }\end{array}$ \\
\hline
\end{tabular}




\begin{tabular}{|l|l|l|l|}
\hline \multicolumn{1}{|c|}{$\begin{array}{c}\text { On-the-Ground } \\
\text { Activism }\end{array}$} & \multicolumn{1}{|c|}{ Online Efforts } & Solidarity Efforts & Legislative Support \\
\hline $\begin{array}{l}\text { Naelyn Pike speaking } \\
\text { at a Presidential } \\
\text { candidate Bernard } \\
\text { Sanders rally }\end{array}$ & $\begin{array}{l}\text { Creation of online } \\
\text { crowd funding page to } \\
\text { support Apache } \\
\text { Stronghold's journey } \\
\text { to Washington DC }\end{array}$ & & \\
\hline
\end{tabular}

Table 4: Examples of Types of Activist Efforts Associated with Oak Flat Activism

\section{Discussion}

The findings of this study reveal narratives of survivance (Vizenor, 1994; Vizenor, 1999) and the celebration of survival (Smith 2012) as framed by Oak Flat and Apache Stronghold activists as expressed via social media. Smith (2012) describes that the celebration of survival is a way to document the active resistance of colonialism. Celebrating survival can be further seen as celebrating both "survival and resistance", or survivance (Smith, 2012, p.146) and can appear as stories, arts, music, or events where there is celebration of life, all of which have been observed in social media surrounding Oak Flat activism. Gerald Vizenor (2008) describes multiple narratives of Native survivance that reframe Native existence from that of victimhood to activist resistance. In narratives of survivance, Natives are not victims of colonisation but rather are resisters who have survived colonialism. And so, how might survivance be portrayed in digital activism to influence social change? Considering this approach, the overall implication is that American Indian digital activism blurs the concept of contemporary activism, not just in the interplay of online and on-the-ground activist efforts but also in reframing the dimensions of social change that are possible through digital activism. This is found in three ways: The first being that social media is more than just an activist tool for the amplification of voice, dissemination of information, and coordination of collective actions, but also as tool to showcase survivance. The second is that one intended social change of American Indian digital activism is not just to influence individuals within social networks so they can influence political actors, or be more civically engaged, but also to influence survivance among individuals in their networks and communities, or, in other words to heal. The third is that to celebrate survival is also to understand the important role that American Indian youth, such as Naelyn Pike, have in American Indian activism; American Indian youth are the ultimate form of colonial resistance as they represent life and a specific Indigenous future orientation. These narratives can be observed through Apache Stronghold's activist efforts as expressed through on-the-ground and online efforts.

\subsection{American Indian Digital Activism is Survivance}

In this study, Apache Stronghold's activist efforts as portrayed through social media include many aspects of contemporary activism. Specifically, such on-the-ground activist efforts are identified as physical occupation of space such as sit-ins, civic activism such as demonstrations and petition signing, efforts to influence the legislative process, and efforts to increase awareness about the cause to save Oak Flat. While the findings indicate an interplay between online (e.g. the creation of petitions in an online civic engagement platform, information dissemination) and on-the-ground activist efforts, further examination of the themes of Apache Stronghold's social media reveal another aspect of American Indian activism that can be observed in both activist efforts on-the-ground and online, that of survivance.

Drawing from Smith, survivance "accentuates the degree to which indigenous peoples and communities have retained cultural and spiritual values and authenticity in resisting colonialism" (2012, p.146). Survivance has been defined as "survival and resistance" (Smith, 2012, p.146), but is an interpretation of Vizenor's description of survivance, which is "an active sense of presence over absence, deracination, and oblivion; survivance is the continuance of stories, not a mere reaction, however pertinent" (Vizenor, 2008, p.1). While Vizenor discusses 
survivance as literary theory and practice, survivance was also observed in the social media content surrounding the efforts of Oak Flat activists.

The findings of the emerging themes of Apache Stronghold's social media content showcase aspects of cultural and spiritual survival and the continuance of Native stories; it showcases activist efforts are an active presence. The role of culture in American Indian activism is then perhaps more deep and complex than simply observing culture in activist efforts but rather the active presence of culture, its survival from colonial attempts to dominate and assimilate American Indian peoples and the continuance of culture, is activism. For example, Figure 1 depicts Naelyn Pike wearing moccasins, a camp skirt, and holding a bow and arrow. At the surface one could make an observation that the outfit is fashion, or a way to express cultural pride, but it is an active presence of culture compared to the display of cultural artifacts in a museum. The active presence of culture and spirituality were observed through Apache Stronghold social media content that depicted spiritual runs, the use of traditional objects in walks, traditional regalia worn by activists who are in photos and videos, speaking traditional language in videos, symbols of life in media content such as hummingbirds and stars, and the spiritual connection to place and land as described by activists. Not only have cultural and spiritual values been retained but the active presence of culture also celebrates the survival of a group of people.

\subsection{American Indian Digital Activism is Healing Communities}

Research on digital activism has focused on how the Internet and social networking sites are used to coordinate activists' efforts, build networks (Juris, 2005), constrain the exposure of messages outside of ideological clusters (Himelboim, McCreery, \& Smith, 2013), and influence social movement coverage (Malinick, Tindall, \& Diani, 2013). Even if the use of social networks only increases the exposure of a cause within like-minded clusters, gaining access to such a network could prove beneficial to Oak Flat activists if it results in gaining supporters who may be willing to click a button, sign an online petition, or otherwise proactively contribute to the overall cause. The findings indicate that Oak Flat and Apache Stronghold digital activism and collective action mobilisation has received a fair amount of media attention from Native American focused news outlets, local news outlets, and national news outlets (e.g. coverage in Indian Country Today Media Network, Phoenix New Times, New York Times). The movement has gained support from prominent political actors such as Senator Bernie Sanders and Congressman Raúl Grijalva, and even received a response from the 'We The People' White House petition from Jodi Gillette, Special Assistant to President Barack Obama for Native American Affairs, titled "We'll Work With Tribes to Protect Sacred Land" (Gillette, 2015). The use of hashtags to connect Apache Stronghold's network to larger Indigenous movements and connect Oak Flat activists with other American Indian activist groups such as the American Indian Movement, Moccasins On The Ground, Indigenous Environmental Network, and Tó Bei Nihi Dziil (Water Gives Us Power), presents an interesting insight into how American Indian digital activism influences social change within networks and beyond the desired influence on political actors.

The findings of this study suggest that Oak Flat activism has made considerable contributions to influence political actors who have the means to implement policies that can save Oak Flat. However, approaching the findings from the standpoint of celebrating survival further suggests that macro social change, healing communities, can also come from influencing one's own networks, including within social networks that center the survivance of Indigenous peoples. For example, Jacob (2013) discusses how strengthening Yakama culture through revitalisation efforts is not only an act of bringing back into practice culture, traditions, and language, but also is an act of healing from the destructions of colonisation. Apache Stronghold showcasing the survival and resistance of their culture and people with their network of American Indian activist groups is thus promoting the healing of Indigenous peoples in their own cultural ways. It is empowering to realise that the collective action of many Indigenous groups healing through activism represents the basis of a societal change. 


\subsection{American Indian Digital Activism is a Future Orientation}

This study brought into focus how Apache Stronghold celebrates survival through Apache culture and how youth are the embodiment of life, which is the ultimate form of colonial resistance. The presence of American Indian youth was an emerging theme in Apache Stronghold's social media content. In particular, Naelyn Pike, an American Indian youth activist of Apache Stronghold was a prominent and actively present figure in Oak Flat activism. Naelyn was also observed as an emerging spokesperson and she appears in many photos where she appears to be speaking to audiences of many sizes, including the U.S. Congress, and in videos talking about the significance of Oak Flat to the San Carlos Apache people. While Naelyn is the most recognisable youth in social media content surrounding Oak Flat activism, other youth are featured at the start of spiritual runs and marches, and are photographed being present in Oak Flat.

The significance of American Indian youth in social media activism cannot be overstated. Symbolically, youth in American Indian cultures represent life, the continuance of people and their stories, and the future of a tribe. For example, the Seven Generations philosophy refers to the intergenerational teaching and planning of an Indigenous community keeping in mind that the impacts of such actions today will reverberate and be felt by future generations (Jacob, 2013). Youth then are an important part in the transmission of cultural knowledge and survival of traditions and future communities.

\section{Conclusion}

In sum, this case study provides a snapshot of aspects shaping contemporary American Indian activism in digital and on-the-ground moments, in particular with regard to a single environmental rights issue, \#SaveOakFlat. This study provides insight into the content of social media that are shared by Apache Stronghold activists in their efforts to protect Oak Flat as well as different groups that activists are working with, possibly from different networks. Oak Flat activists are connected with local and national activist groups, organisations, and congressional members who are in some form supporting the efforts to save Oak Flat. Activism around Oak Flat is also the combination of on-the-ground and online efforts and a demonstration of resistance. Future studies may incorporate observations of on-the-ground efforts and look further into the relationships and connections between Apache Stronghold and their allies, which may provide a thorough and rich analysis of the phenomenon to protect Oak Flat.

This study also highlights the importance of the timeline and the mapping of critical events in social media studies, and in particular with regard to Indigenous activism. As of this writing, the current Donald J. Trump presidency in the United States has engaged in a number of acts, including the crafting of a series of executive orders and efforts to eliminate key policy and regulatory measures, that threaten various contemporary American Indian activist and environmental justice movements in the U.S. Thus, the timeline also provides context into the form of government shaping the digital activism of American Indian activists in certain historical moments.

Overall, understanding the interplay between specific cases of contemporary American Indian activism and the use of social media to express narratives of survivance, and culture and survival makes room for understanding the decolonisation of colonial spaces such as the Internet and social media platforms (Gaertner, 2015). Centering the expressions, goals and experiences of American Indian activists while analysing social media data is one way that social media researchers can better understand dimensions of social change through digital means.

\section{References}

Amerman, S. K. (2003). "Let's Get in and Fight!": American Indian political activism in an urban public school system, 1973. The American Indian Quarterly, 27(3\&4): 607-638. 
Apache Stronghold. (2016, February). Once again, the fight for religious freedom in American begins. Retrieved from http://apache-stronghold.com/about.html

Barberá, P., Jost, J. T., Nagler, J., Tucker, J. A., \& Bonneau, R. (2015). Tweeting from left to right: Is online political communication more than an echo chamber? Psychological Science, 26(10): 1531-1542.

Brainerd Dispatch. (2017, January 17). Mille Lacs Band splits business from Wells Fargo. Brainerd Dispatch. Retrieved from http://www.brainerddispatch.com/news/4200190mille-lacs-band-splits-business-wells-fargo

Chappell, B. (2017, February 8). 2 cities to pull more than $\$ 3$ billion from Wells Fargo over Dakota Access Pipeline. NPR. Retrieved from http://www.npr.org/sections/thetwoway/2017/02/o8/514133514/two-cities-vote-to-pull-more-than-3-billion-from-wellsfargo-over-dakota-pipelin

Conner, T. W. (2014). Exploring voting behavior on American Indian legislation in the United States Congress. The Social Science Journal, 51: 159-166.

Corbin, J. \& Strauss, A. (2015). Basics of Qualitative Research. Techniques and Procedures for Developing Grounded Theory. Fourth Edition. Los Angeles: Sage.

Cunha E., Magno, G., Goncalves, M. A., Cambraia, C., \& Almeida, V. (2014). He votes or she votes? Female and male discursive strategies in Twitter political hashtags. PLoS One, 9(1). doi: 10.1371/journal.pone.0087041

Democracy Now!. (2016, November 16). Worldwide protests demand U.S. Army reject Dakota Access Pipeline. Democracy Now!. Retrieved from https://www.democracynow.org/2016/11/16/headlines/worldwide_protests_demand _us_army_reject_dakota_access_pipeline

Dreher, T., McCallum, K., \& Waller, L. (2015). Indigenous voices and mediatized policymaking in the digital age. Information, Communication \& Society, 19(1): 23-39.

Federal Register. (2000, November 6). Executive Order 13175 of November 6, 2000. Consultation and coordination with Indian tribal governments. Vol 65 (218): 6724967252. Washington, DC: Federal Register

Gaertner, D. (2015). Indigenous in cyberspace: CyberPowWow, God's Lake Narrows, and the contours of online Indigenous territory. American Indian Culture and Research Journal, 39(4): 55-78.

Gillette, J. (2015, January 9). Official The White House response to "Stop Apache Land Grab", We'll work with tribes to protect sacred land. Retrieved from https://petitions.whitehouse.gov/response/well-work-tribes-protect-sacred-land

Graeff, E., Stempeck, M. \& Zuckerman, E. (2014). The battle for ‘Trayvon Martin': Mapping a media controversy online and off-line. First Monday, 19(2). doi:10.5210/fm.v19i2.4947

Greenleigh, I. (2013). The Social Media Side Door: How to Bypass the Gatekeepers to Gain Greater Access and Influence. New York, NY: McGraw-Hill.

Grinberg, E. (2016, November 4). Sarandon asks you to empty bank account to protest Dakota pipeline. CNN. Retrieved from http://www.cnn.com/2016/11/o3/entertainment/susansarandon-dakota-pipeline-petition/

Harlow, S., \& Guo, L. (2014) Will the Revolution be Tweeted or Facebooked? Using Digital Communication Tools in Immigrant Activism. Journal of Computer-Mediated Communication, 19(3): 463-478.

Himelboim, I., McCreery, S., \& Smith, M. (2013). Birds of a feather tweet together: Integrating network and content analyses to examine cross-ideology exposure on Twitter. Journal of Computer-Mediated Communication, 18: 154-174. 
Jacob, M. M. (2013). Yakama rising: Indigenous cultural revitalization, activism, and healing. Tucson, AZ: The University of Arizona Press.

Jewell, S. (2014, December 19). Statement by Interior Secretary Sally Jewell on the National Defense Authorization Act for Fiscal Year 2015. [Press Release]. Retrieved from http://www.doi.gov/news/pressreleases/statement-by-interior-secretary-sally-jewellon-the-national-defense-authorization-act-for-fiscal-year-2015.cfm

John, S. (2015). Idle No More - Indigenous activism and feminism. Theory in Action, 8(4): 38-54.

Juris, J. S. (2005). The new digital media and activist networking within anti-corporate globalization movements. The Annals of the American Academy of Political and Social Science, 597: 189-208.

Knopf, K. (2010). "Sharing our stories with all Canadians": Decolonizing Aboriginal media and Aboriginal media politics in Canada. American Indian Culture and Research Journal, 34(1): 89-120.

Lenhardt, C. (2016). "Free Peltier Now!" The use of Internet memes in American Indian activism. American Indian Culture and Research Journal, 4O(3): 67-84.

Loeffelholz Dunn, T. (2016, December 6). The numbers that tell the story of this Standing Rock victory. YES! Magazine. Retrieved from http://www.yesmagazine.org/peoplepower/numbers-tell-the-story-of-the-standing-rock-sioux2019s-victory-20161204

Malinick, T. E., Tindall, D. B., \& Diani, M. (2013). Network centrality and social movement media coverage: A two-mode network analytic approach. Social Networks, 35: 148-158.

Medina, D. A., \& Davis, R. (2016, December 9). Veteran finds forgiveness, peace in Standing Rock fight. NBC. Retrieved from http://www.nbcnews.com/storyline/dakota-pipelineprotests/veteran-finds-forgiveness-peace-standing-rock-fight-n694226

Moscato, D. (2016). Media portrayals of hashtag activism: A framing analysis of Canada's \#Idlenomore movement. Media and Communication, 4(2): 3-12.

Rambler, T. (2015, January 27). All Nations gathering. Indian Country Today Media Network. Retrieved from https://indiancountrytodaymedianetwork.com/2015/01/27/allnations-gathering-158879

Revkin, A. C. (2015, July 17). From Times Square to the Capitol, Apache protestors fight U.S. land swap with mining company. The New York Times. Retrieved from https://mobile.nytimes.com/blogs/dotearth/2015/o7/17/from-times-square-to-thecapitol-apache-protestors-fight-u-s-land-swap-with-mining-company/

Richland, J. B. \& Deer, S. (Eds.). (2010). Introduction to tribal legal studies (2nd ed.). Lanham, MD: Alta Mira Press.

Risling Baldy, C. (2016). The new Native intellectualism. \#ElizabethCook-Lynn, social media movements, and the millennial Native American studies scholar. Wicazo Sa Review, 31(1): 90-110.

Rockwell, S. J. (2010). Indian affairs and the administrative state in the Nineteenth Century. Cambridge, NY: Cambridge University Press.

Small, T. A. (2011). What the Hashtag? A content analysis of Canadian politics on Twitter. Information, Communication \& Society, 14(6): 872-895.

Smith, L. T. (2012). Decolonizing methodologies. Research and Indigenous peoples ( $2^{\text {nd }}$ ed.). United Kingdom: Zed Books.

Sewell, Jr., W. H. (2005). Logics of history: Social theory and social transformation. Chicago, IL: University of Chicago Press. 
Toensing, G. C. (2014, December 8). San Carlos Apache leader seeks Senate defeat of copper mine on sacred land. Indian Country Today Media Network. Retrieved from http://indiancountrytodaymedianetwork.com/2014/12/o8/san-carlos-apache-leaderseeks-senate-defeat-copper-mine-sacred-land-158181

Toensing, G. C. (2015, January 27). San Carlos Apache leader: 'What was a struggle to protect our most sacred site is now a battle'. Indian Country Today Media Network. Retrieved from http://indiancountrytodaymedianetwork.com/2015/01/27/san-carlos-apacheleader-what-was-struggle-protect-our-most-sacred-site-now-battle-158878

Turner, C. (2005). Politics of minor concern. Oxford, UK: University Press of America.

U.S. Census Bureau. (2012). The American Indian population: 2010. Washington, D.C.: U.S. Census Bureau. Retrieved from http://www.census.gov/prod/cen2010/briefs/c2010br10.pdf

Valenzuela, S (2013). Unpacking the Use of Social Media for Protest Behavior: The Roles of Information, Opinion Expression, and Activism. American Behavioral Scientist, 57(7): 920-942.

Vigil-Hayes, M., Duarte, M., Deschine Parkhurst, N., Belding, E. (2017). \#Indigenous: Tracking the connective actions of Native American advocates on Twitter. $2 O^{\text {th }} A C M$ Conference on Computer-Supported Cooperative Work and Social Computing (CSCW 2017), February 25-March 1, 2017, Portland, Oregon.

Vizenor, G. (1994). Manifest manners: Postindian warriors of survivance. Hanover, N.H: Wesleyan University Press.

Vizenor, G. (1999). Manifest manners: Narratives of postindian survivance. Lincoln, NE: University of Nebraska Press.

Vizenor, G. (2008). Survivance: Narratives of Native presence. Lincoln, NE: University of Nebraska Press.

Walker, T. (2014, November-December). 8 top social media conversations, starting with \#RockYourMocs. Retrieved from http://www.nativepeoples.com/NativePeoples/November-December-2014/Going-Social/

Wasser, M. (2015, August 17). John McCain confronted by Oak Flat protesters and chased off Navajo Nation. Phoenix New Times. Retrieved from http://www.phoenixnewtimes.com/news/john-mccain-confronted-by-oak-flatprotesters-and-chased-off-navajo-nation-7570607

Copyright: (C) 2017 Deschine Parkhurst. This is an open-access article distributed under the terms of the Creative Commons Attribution-NonCommercial 3.0 Australia License, which permits non-commercial use, distribution, and reproduction in any medium, provided the original author and AJIS are credited.

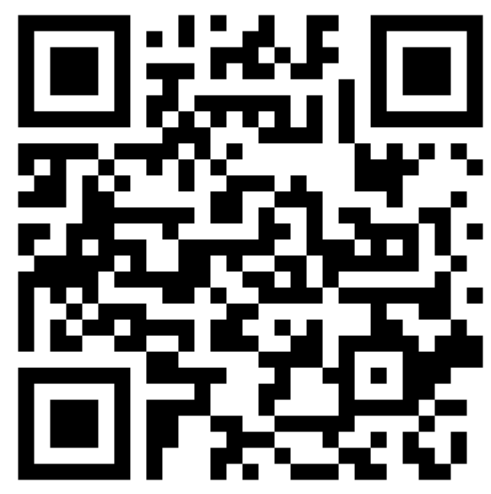

